УДК $82-94+911.3$

DOI: 10.33184/YVDK-2021-04-30.34

А.М. Харитонов (науч. сотр. ТИГ ДВО РАН, 2. Владивосток)

\title{
ГДЕ ИСКАТЬ «КОЛДОВСКОЙ» ЗАЛИВ?
}

B cтатье рассматриваются возможные варианть местонахождения залива Гандвик. Вылелены типичные географические ошибки, которые привели к неправильному толкованию географического положения в сагах изначального залива. Получены довольно неожиданные результаты, которые, похоже, подтверждают достоверность некоторых книжных легенд.

Ключевые слова: Азовское море, Балтийское море, Белое море, Гандвик, Северньй Ледовитьй океан

The article discusses possible variants of the origin of the location of Gandvik Bay. Typical geographical errors that led to the misinterpretation of the geographical position in the sagas of the primordial gulf are highlighted. Quite unexpected results have been obtained, which seem to confirm the validity of some book legends.

Key Words: Sea of Azov, Baltic Sea, White Sea, Gandvik, Arctic Ocean

Традиционное восприятие залива Гандвик известного из текстов скандинавских саг в современной норманистской географической литературе - Северный Ледовитый океан и Белое море в частности [см. Древняя Русь ... 2009б]. Иногда в качестве данного залива называют также Кандалакшскую (Ганд + финское «лахти», что значит «залив») губу Белого моря.

При этом обычно начисто забывается, что это понятие имеет еще и некоторый древний мифологический оттенок. Ведь по некоторым этимологиям имя залива связывают с колдовством. На его берегах сказания часто помещают великанов и других сказочных чудовищ.

Правда, далеко не все согласны с положением залива Гандвик на Крайнем Севере. Имеется предположения о его 
возможном положении и на месте современного Ботнического залива Балтийского моря. В частности, эту версию можно разрабатывать на основании того, что название Гандвик в древности относилось ко всей территории Балтики по словам Саксона Грамматика. Впрочем, есть сведения и о географическом размещении Гандвика между Гренландией и Биармией.

В пользу сугубо северной версии нахождения залива как раз обычно и приводят наличие на его берегах страны Биармии, известной своей рекой Виной, развитым земледелием и большим разнообразием мехов, в т.ч. бобра. По этим основаниям Биармию вместе с рекой Виной и помещают на месте Северной Двины сегодня.

И это при том, что бобр здесь не водится, а земледелие по данным археологии развито было весьма скудно. Да и следов пребывания норманнов в данном регионе археологи так и не смогли отыскать, хотя поработать в данном направлении изначально старались они изрядно.

Кстати, размещение каких-либо объектов на территории вокруг Белого моря в раннем средневековье категорически не принимает географическая наука средних веков. Именно об этом забывают даже те авторы, которые не согласны с ранними плаваниями западноевропейцев в полярных водах [Никитин 1976 и др.].

Ведь даже наиболее развитая арабская география считала земли севернее реки Дон незаселенными [Галкина 2002], следуя прямым указаниям Аристотеля [1981] о необитаемости территорий холодного климатического пояса. При этом арабы хорошо знали Русь и Киев, однако Варяжским морем считали ... Меотиду, т.е. Азовское море [Древняя Русь ... 2009а].

Кстати, иногда «туманный» характер залива Гандвик пытаются связать с колдовским мотивом исчезновения самого залива. Ведь при густом тумане видимость на море порой падает до нуля. Неплохое объяснение в духе средневековых кеннингов (иносказаний). Вот только сам залив при этом остается, конечно, на месте. «Колдовским» бы он стал, если бы мог действительно появляться и исчезать по своему усмотрению.

Впрочем, исчезновение и появление небольших мелководных бухточек и заливчиков при приливе и отливе иногда имеет место. Но, конечно, чудесного в этом ничего нет. В Белом 
море высокая величина приливов даже позволяет строить приливные электростанции.

Любопытно, однако, что географии известен один достаточно крупный залив, способный время от времени полностью исчезать! Вот только к Скандинавии он не имеет никакого отношения.

Если вернуться на сотню лет назад, то можно напомнить, что Красная армия штурмовала белогвардейский Крым по разным направлениям. Сугубо сухопутным при этом было только Перекопское, но существовали также возможности сравнительно несложной в мирное время переправы в Крым с севера через Чонгарский перешеек и даже Арабатскую стрелку.

Не менее известна историкам также попытка переправы в Крым прямо через залив Сиваш по его дну. Ведь местным жителям были известны броды через залив, которые обнажались при благоприятном направлении ветра. Правда, в самый момент переправы ветер внезапно изменил направление, но и это не помешало части войск все-таки прорваться в нужном направлении.

Сиваш (Гнилое море) - очень крупный (порядка 2500 кв. км$^{2)}$, но мелководный (в среднем 0,5-1, максимально 3 м глубины) географический объект. Примерно четвертая часть его площади покрывается водой лишь периодически. Острова занимают до 100 кв. км ${ }^{2}$ его площади. Летом сильно прогревается, из-за этого вода приобретает гнилостный запах. Длина залива порядка 200 км, ширина 2-35 км. Дно покрыто слоем ила до 5 м толщиной.

Известен залив еще античной географии, хотя не всегда ею прямо выделялся из современного Азовского моря. Дело в том, что само Азовское море, частью которого Сиваш сегодня является, в античности считалось не морем, но болотом Меотидой. Некоторые авторы считают даже, что тогда в античности уровень моря падал на 6-10 м [Долуханов 1988]. При этом минимальный уровень воды в море наблюдался в 5-3 веках до н.э. В раннем средневековье, наоборот, уровень воды вырос по сравнению с современным.

Правда, при таком падении уровня моря не слишком понятна возможность существование тогда Киммерийского (современного Керченского) пролива. Ведь его глубина сегодня порядка 5 м, а само Азовское море при таком падении уровня 
должно было исчезнуть. Ведь его максимальная глубина порядка 15 м. Разве что на месте «глубоководной» котловины в его центре осталось бы небольшое озеро, через которое должна была течь современная река Дон и впадать в Черное море в районе современного Керченского пролива.

Получается, что исчезающим могло быть и само Азовское море, которое средневековая география сплошь и рядом называет Балтийским морем [см. Харитонов 2020 и др.]. Но при чем здесь Гандвик и Гренландия?

Дело в том, что происхождение топонима Гренландия (зеленый остров) не столь ясное, как представляется. В средние века подобным образом назывался ... Крым [Смирнов 2011].

Так что размещение Гандвика между Гренландией и Биармией вполне могло иметь место в «древние времена», а совсем не в средневековье, что и сохранила для нас география. Она же на одной из арабских карт показала наличие Биармии на ... Северном Кавказе, что было отмечено финским переводчиком, но предано забвению [см. Харитонов 2013 и др.].

Впрочем, несогласные с размещением Биармии на Севере чаще стараются разместить ее в Прибалтике [см. Магидович В.И., Магидович И.П. 2003 и др.] по берегам уже Западной Двины.

Не следует также забывать, что сами норманны не считали себя аборигенами современной Скандинавии, хотя и выводили себя с острова Сканда. По их мнению, в Западную Европу они пришли из Скифии (Причерноморья). Именно здесь наши летописи размещают летописных северян (аналог этнонима норманны).

Как отмечает один из современных исследователей происхождения географических названий [см. Курбатов 2005 и др.] тенденция перемещения топонимов вслед за первоначальными носителями является достаточно стойкой. При этом подобные топонимы частенько занимают обширные ареалы или размещаются цепочками, по которым можно проследить перемещение их носителей. Вот потому современные норманисты и приняли конечные пункты перемещения топонимов за изначальные, благо это вполне соответствовало их чаяниям.

Что касается наличия чудовищ... Есть такой персонаж Хашховыло в мифологии адыгов - прибрежное морское существо с головой собаки и туловищем быка. Попробуйте угадать, что это 
такое. По мнению автора - морж. Известно, что северные млекопитающие изредка встречаются и на юге. Каспийский тюлень живет там до сих пор, а вот моржа истребили еще в эпоху Ивана Грозного [см. Верещагин 2003].

Какие-то пути из Черного моря в Каспийское существовали и в древности. Географические переводы содержания источников античности и средних веков изредка содержат свидетельства соединения Черного моря с Каспийским каким-то проливом. Вероятно, это была переволока. А потому Северный океан, соединенный с Каспием, возможно, путали с существовавшим топонимом Ахшайна (иранское - темный, черный) для Черного моря.

Так что морж вполне мог стать персонажем кавказской мифологии. Правда, современная Адыгея ближе к Черному, чем к Каспийскому морю. Неужели и в Азовском море когда-то могли водиться моржи? Суровые зимние условия (иногда море может и полностью замерзнуть) в принципе могли бы это позволить.

С Азовским морем можно попытаться связать еще одну сказочную историю. В скандинавской мифологии имеются некие Фенья и Менья - пленные великанши, якобы виновные в осолонении моря, в котором плавал их корабль. Как раз Азовское море испытывает серьезные перепады в уровне солености в разные исторические периоды.

Считается, что увеличение последнего ведет к уменьшению вылова ценных пород рыб, которыми море было весьма богато. В нем, как и в Балтийском море, пресноводные рыбы встречаются вблизи устьев некоторых крупных рек. Да и сильно минерализованный залив Сиваш порой распресняется, когда в него поступает лишняя вода, оставшаяся после орошения полей. Не внезапное ли осолонение прежде пресного водоема послужило причиной возникновения подобных легенд и сказок?

История о сёстрах Фенье и Менье есть в частности в «Младшей Эдде» [2006] Снорри Стурлуссона. Но если имя Феньи производят от feni «болото», то и в русском летописании есть народ дреговичи, т.е. «болотники». Да и Азовское море считалось болотом. А вот одноглазые аримаспы вполне сошли бы и за более поздних кривичей. Очень любопытные и вряд ли случайные совпадения! О древлянах-тервингах можно и вовсе не упоминать, благо византийцы считали их жителями Крыма. 
Современный автор [Кривошеев 2009] предполагает у северных берегов Азовского моря размещение каких-то мадьяр по данным топонимики. Венгров сегодня лингвисты помещают в уральскую (угро-финскую) языковую семью, тогда как в средние века их относили исключительно к «туркам». Но возможно они лишь задержались здесь, огибая море при переселении на новую родину, и попутно позаимствовали ряд иностранных слов из финских языков?

Ведь Азовское море считалось в античности одним из мест обитания амазонок. Именно с ними можно попытаться связать сестер-великанш (етунов). Помнится, легенды приписывают появление амазонок в этих местах с захватом ими корабля, где они были пленницами. Похоже, все эти сведения не столь фантастичны, как обычно считается в исторической литературе и скорее всего даже как-то взаимосвязаны.

Нет ли связи и в названии некой северной страны Туле античности и венгерского имени Дьюла (из титула?). Ведь венгры действительно жили где-то на северном краю античной ойкумены (обитаемой зоны в географии античности).

Получается, что в случае правильной географической привязки текста легенд к условиям местности возможно добиться весомых результатов даже в сугубо фантастическом литературноисторическом исследовании. Но для этого необходимо строго придерживаться правила ограниченности географических представлений античности и ранних средних веков. В противном случае рано или поздно придется переводить выходящие за данные рамки сочинения в разряд альтернативной истории.

\section{ЛИТЕРАТУРА}

1. Аристотель. Сочинения. В 4-х т. Т. 3: Перевод / Вступ. статья и примеч. И.Д. Рожанский. - М.: Мысль, 1981. - 613 с.

2. Верещагин Н.К. Проблемы создания и хранения териоколлекций в биологических учреждениях России и СНГ. // Природа.- 2003. - №10. - С. 85-88.

3. Галкина Е.С. Тайны Русского каганата. - М.: Вече, 2002. - 430 c.

4. Долуханов П.М. История средиземных морей. - М.: Наука, 1988. - $142 \mathrm{c}$. 
5. Древняя Русь в свете зарубежных источников. Т. III. Восточные источники. - М.: Русский Фонд Содействия Образованию и Науке, 2009а. - 264 с.

6. Древняя Русь в свете зарубежных источников: Хрестоматия. T.V. Древнескандинавские источники. - М.: Русский Фонд Содействия Образованию и Науке, 2009б. - 384 с.

7. Кривошеев А.А. Мадьяры. Исход от Камы до Дуная. - Ростов н/Д: ЗАО «Ростиздат», 2009. - 80 с.

8. Курбатов В.А. Славянские континенты: пути расселения наших предков (V - XIX вв.). - М.: Изд-во Эксмо, Изд-во Алгоритм, 2005. - 382 с.

9. Магидович В.И., Магидович И.П. Очерки по истории географических открытий. Открытия древних народов. М.: Центрполиграф, 2003. - 448 с.

10. Младшая Эдда. - СПб.: Наука, 2006. - 141 с.

11. Никитин А.Л. Биармия и Древняя Русь // Вопросы истории. 1976. -№7. - С. 56-69.

12. Смирнов В.Д. Крымское ханство XIII - XV вв. - М.: Вече, 2011. - $336 \mathrm{c}$.

13. Харитонов А.М. Об описании Балтийского моря в «Деяниях гамбургских архиепископов» Адама Бременского // Языки в диалоге культур: проблемы многоязычия в полиэтническом пространстве: материалы III Всероссийской научнопрактической конференции с международным участием, посвященной 75-летию Победы в Великой Отечественной войне (г. Уфа, 5 июня 2020 г.) / отв. ред. Р.А. Газизов. - Уфа: РИЦ БашГУ, 2020. - С.343-351.

14. Харитонов А.М. О месте Биармии на современной географической карте // Этнокультурное и социальноэкономическое развитие коренных малочисленных народов Севера. - Ханты-Мансийск: ООО «Печатный мир г. ХантыМансийск», 2013. - С.290-301.

Харитонов А.М., 2021 г. 